\title{
Characterizations of Bacterial Cellulose Producing Strain Gluconoacetobacter hansenii CGMCC3917
}

\author{
Dehui Lin, Nan Wang, Zhixi Li ${ }^{\star}$ and Yan Li
}

College of Food Science and Engineering, Northwest A \& F, China

*Corresponding author: Zhixi Li, College of Food Science and Engineering, Northwest A \& F University, No. 28 Xinong Road, 712100, Yangling, Shaanxi, China, Tel: 86-13571939821; E-mail: Izx580721@yahoo.com.cn

Rec date: May 05, 2014; Acc date: May 21, 2014; Pub date: May 27, 2014

Copyright: (C) 2014 Lin D, et al. This is an open-access article distributed under the terms of the Creative Commons Attribution License, which permits unrestricted use, distribution, and reproduction in any medium, provided the original author and source are credited.

\begin{abstract}
Gluconoacetobacter hansenii CGMCC3917 ( $\left.\mathrm{M}_{438}\right)$, isolated from inoculums of strain $\mathrm{J}_{2}$ treated by high hydrostatic pressure, has strong ability of producing cellulose as more than three times as that of its initial strain $\mathrm{J}_{2}$. In this paper, in order to further study the effects of high hydrostatic pressure treatment on characterizations of strain $\mathrm{J}_{2}$ on the basis of previous study, properties of these two strains were examined and compared. The results indicated that the mutant strain $\mathrm{M}_{438}$ and its initial strain $\mathrm{J}_{2}$ had different Phenotypic Characterizations in liquid seed medium. The fermentation parameters showed that cell growth rate of strain $\mathrm{M}_{438}$ was relatively higher than that of strain $\mathrm{J}_{2}$, namely, residual sugar, residual nitrogen and acidity of strain $M_{438}$ were less than that of strain $J_{2}$. Furthermore, water holding capacity (WHC) and water release rate (WRR) of bacterial cellulose (BC) membranes produced by $\mathrm{M}_{438}$ were both better than those of $\mathrm{BC}$ membranes produced by $\mathrm{J}_{2}$. However, SEM imagines suggested that there was no evidence difference in microstructure of BC membranes. Additionally, FT-IR also showed no difference between BC membranes produced by strain $M_{438}$ and its initial strain $\mathrm{J}_{2}$.
\end{abstract}

Keywords: Gluconoacetobacter hansenii; Bacterial cellulose; Characterizations; High hydrostatic pressure

\section{Introduction}

Gluconacetobacter hansenii is gram negative, rod, straight or slightly curved, singly or in pairs, belonging to the family Acetobacteraceae within the Alphaproteobacteria class of the Proteobacteria phylum [1]. It was reported that a notable feature of this bacterium has been found is to secrete extracellular cellulose in the form of a pellicle at the air-liquid interphase, which is commonly referred to as bacterial cellulose (BC) [1]. BC, being an eco-friendly biomaterial, differs from plant cellulose in chemical and physical features. It exhibits higher purity, higher crystallinity, higher degree of polymerization, higher water absorbing and holding capacity, higher tensile strength, and stronger biological adaptability [2-5]. Due to its unusual physicochemical and mechanical properties, $\mathrm{BC}$ presents a potential alternative to plant-derived cellulose for specific applications in bio-medicine, cosmetics, high-end acoustic diaphragms, papermaking, food industry and other applications [6-10].

High hydrostatic pressure (HHP) is a well-known physical stress, causing various effects on a variety of cellular structures and functions. It can interfere with the processes of polymerization and depolymerization of proteins which are essential for the formation and functioning of the mitotic structure and its stability [11]. Additionally, reactivity of some enzymes has been shown to be affected by hydrostatic pressure [12]. Therefore, it has been used to as a useful mutating method to cause mutagenesis to Esherichia coli, Streptococcus lactis and Bacillus subtilis [13]. In our previous work, $\mathrm{BC}$-producing strain $\mathrm{J} 2$, screened from homemade vinegar under static condition, was treated by HHP for $15 \mathrm{~min}$ at $250 \mathrm{MPa}, 25^{\circ} \mathrm{C}$ and then a mutant strain $\mathrm{M}_{438}$ was obtained. Its $\mathrm{BC}$ yield (dry weight) increased from $1.08 \mathrm{~g} \mathrm{~L}^{-1}$ to $3.58 \mathrm{~g} \mathrm{~L}^{-1}$ under the same condition
[14,15]. Additionally, the mutant strain $\mathrm{M}_{438}$ and its initial strain $\mathrm{J}_{2}$ were identified as Gluconacetobacter hansenii subsp. nov. and a varietas of Ga. Hansenii based on 16S rRNA gene sequences respectively [14].

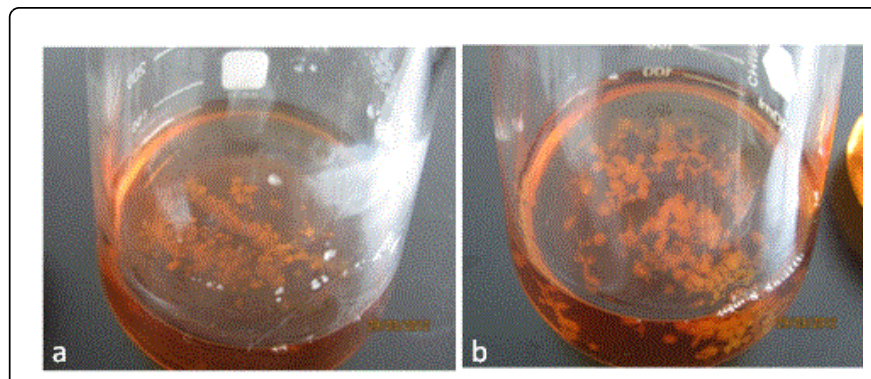

Figure 1: Colony shape of bacterial strain $\mathrm{J}_{2}(\mathrm{a})$ and $\mathrm{M}_{438}$ (b) in the seed medium.

In the present study, in order to further study the effects of HHP treatment on characterizations of strain $\mathrm{J}_{2}$ on the basis of previous study, colonial morphologies in the liquid medium and fermentation parameters including residual nitrogen, residual sugar, the total acidity and cell density, were determined and compared. In addition, water holding capacity (WHC) and water release rate (WRR) of the bacterial cellulose were measured. Its microstructure was observed using scanning electron microscopy (SEM) and its chemical bonds were determined using Fourier transform infrared spectrometry (FT-IR). 


\section{Materials and Methods}

\section{Microorganism and $\mathrm{BC}$ preparation}

The mutant strain $\mathrm{M}_{438}$, deposited as CGMCC3917 at China General Microbiological Culture Collection, Beijing, China, was used in the present study and maintained on glucose agar slants containing: $20 \mathrm{~g}$ glucose $\mathrm{L}^{-1}, 5 \mathrm{~g}$ yeast extract $\mathrm{L}^{-1}, 1 \mathrm{~g} \mathrm{~K}_{2} \mathrm{HPO}_{4} \mathrm{~L}^{-1}, 15 \mathrm{~g}$ $\mathrm{MgSO}_{4} \cdot 7 \mathrm{H}_{2} \mathrm{O} \mathrm{L}-1,15 \mathrm{~mL}$ ethanol L $\mathrm{L}^{-1}$, and $17 \mathrm{~g}^{-1}$ agar L $\mathrm{L}^{-1}$. The strain was cultured at $30^{\circ} \mathrm{C}$ for $12-18 \mathrm{~h}$, then stored at $4^{\circ} \mathrm{C}$ in a refrigerator and sub-cultured every 2 months for inoculum development or stored at $-80^{\circ} \mathrm{C}$ with $20 \%(\mathrm{v} / \mathrm{v})$ glycerol instead of agar for long-time storage [14].

For producing inoculums, a loop of the strain was transferred from a slant culture into an Erlenmeyer flask $(250 \mathrm{~mL})$ containing $100 \mathrm{~mL}$ seed medium with the same components as glucose agar slants but without agar. The seed cultures were grown at $30^{\circ} \mathrm{C}$ and $150 \mathrm{rpm}$ in a rotary shaker (THZ-82A, Jintan Jieruier Electrical apparatus Co. Ltd., Jiangsu, China) for 12-18 h until it reached the logarithmic growth phase. Then inoculum $(9 \%, \mathrm{v} / \mathrm{v})$ was transferred into a glass vessel $(300$ $\mathrm{mL}$ ) containing $100 \mathrm{~mL}$ of fermentation medium containing: $30 \mathrm{~g}$ carbon source $\mathrm{L}^{-1}$ ) (glucose/sucrose $=2: 1$ ), $5 \mathrm{~g}$ yeast extract $\mathrm{L}^{-1}, 3.6 \mathrm{~g}$ $\mathrm{FeSO}_{4} \mathrm{~L}^{-1}, 3 \mathrm{~g} \mathrm{ZnSO}_{4} \mathrm{~L}^{-1}, 0.8 \mathrm{~g} \mathrm{~K}_{2} \mathrm{HPO}_{4} \mathrm{~L}^{-1}, 16.2 \mathrm{~g} \mathrm{MgSO}_{4} \mathrm{~L}^{-1}, 0.5 \mathrm{~g}$ citric acid $\mathrm{L}^{-1}, 7 \mathrm{~mL}$ ethanol $\left.\mathrm{L}^{-1}\right)$. The starting $\mathrm{pH}$ of the medium was adjusted to 5.0. The glass vessel was covered with 8 layers of gauzes, and then statically cultured at $30^{\circ} \mathrm{C}$ for 14 days [14].

After cultivation, $\mathrm{BC}$ membranes were rinsed with running water overnight, soaked in $0.1 \mathrm{M} \mathrm{NaOH}$ solution at $80^{\circ} \mathrm{C}$ for $2 \mathrm{~h}$, and then washed with deionized water several times to completely remove alkali. The purified cellulose was dried at $105^{\circ} \mathrm{C}$ to constant weight [15].

The medium, culture condition and $\mathrm{BC}$ preparation of strain $\mathrm{J}_{2}$ in this study were as same as those of strain $\mathrm{M}_{438}$ described above.

\section{Phenotypic characterization}

Individual morphologies of strain $\mathrm{M}_{438}$ and $\mathrm{J}_{2}$ were examined in their logarithmic growth phase in liquid seed medium at $30^{\circ} \mathrm{C}$ and 150 $\mathrm{rpm}$ in a rotary shaker incubator.

\section{Fermentation parameters}

Cell density was measured according to Guo et al. methods [16] and modified. One loop of the slant culture incubated for $24 \mathrm{~h}$ was transferred to an Erlenmeyer flask $(500 \mathrm{~mL})$ containing $200 \mathrm{~mL}$ seed medium, and was cultivated at $30^{\circ} \mathrm{C}$ for $72 \mathrm{~h} .5 \mathrm{~mL}$ of cell culture was collected to a test tube under sterile condition at intervals and stored at $4^{\circ} \mathrm{C}$. All the collected cell cultures were mixed with phosphate buffer $(3 \mathrm{~mL}, \mathrm{pH}=5.0)$ containing cellulase $(2 \%, \mathrm{w} / \mathrm{v})(60,000 \mathrm{u} / \mathrm{g}$, Wolsen, China) at $55^{\circ} \mathrm{C}$ for $30 \mathrm{~min}$., and then the mixtures' optical densities at $600 \mathrm{~nm}$ (OD 600) were tested on a UV $=1,700$ PharmaSpec spectrophotometer (Shimadzu, Japan), using culture medium without inoculation as control. Growth curve was drawn with denary logarithm of OD600 x 100 as vertical coordinate and with incubation time as horizontal coordinate [15].

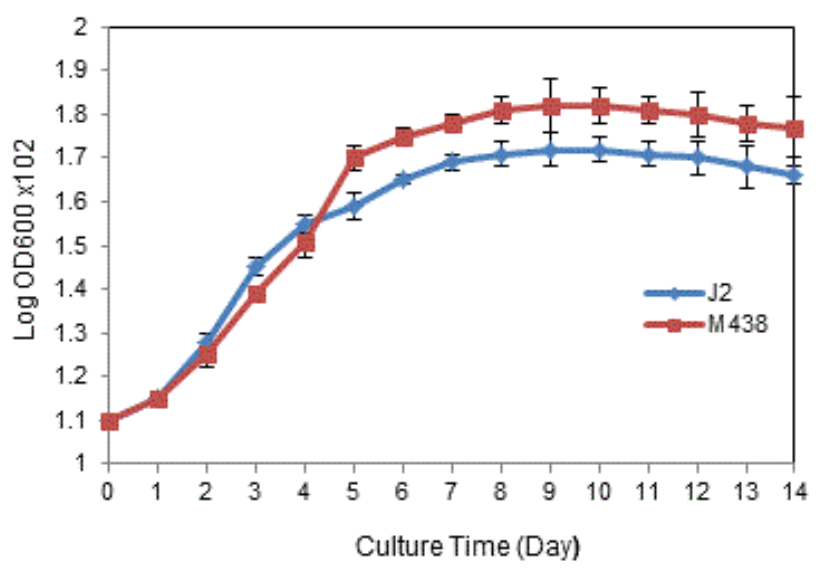

Figure 2: Cell density of strain $\mathrm{J}_{2}$ and strain $\mathrm{M}_{438}$ during 14-day fermentation.

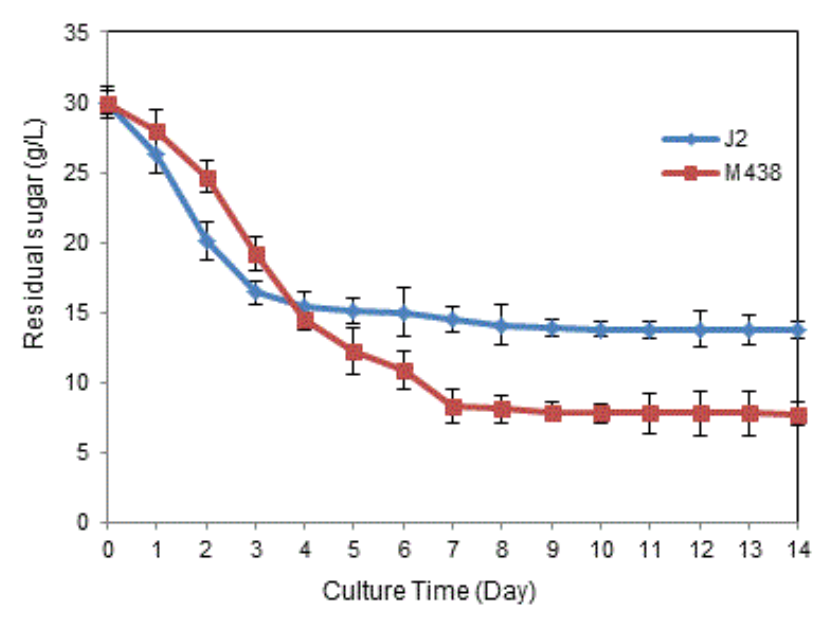

Figure 3: Residual sugar of medium from $\mathrm{J}_{2}$ and $\mathrm{M}_{438}$ during 14day fermentation.

The residual sugar concentration in culture medium was determined by anthrone-sulphuric acid reaction [17].

The residual nitrogen concentration in culture medium was determined by Coomassie brilliant blue (G-250, Sigma) method [18].

The total acidity was measured according to the method of GB/T 12293-90. The result was expressed in the total concentration of acetic acid.

\section{Characteristics of BC membranes}

Water holding capacity: For the determination of WHC, wet BC samples were removed from the storage container with tweezers. The samples were shaken twice quickly and then weighed, and dried at $60^{\circ} \mathrm{C}$ in order to completely remove water in them. WHC was calculated by the following formula [19]: 
Water Holding Capacity = Mass of water removed during drying (g) / Dry weight of cellulose (g)

Water release rate: To determine WRR, Shezad's method [20] was used and modified. The wet $\mathrm{BC}$ membranes from $\mathrm{M}_{438}$ and $\mathrm{J}_{2}$ were cut into small pieces and dried by a freeze dryer (MCFD5508, SIM International $\mathrm{CO}$ ) for $48 \mathrm{~h}$. The dried $\mathrm{BC}$ samples (1g) were subsequently immersed in distilled water under shaking (100 rpm) condition at room temperature for rewetting. After complete rewetting (stabilized wet weight), samples from $\mathrm{M}_{438}$ and $\mathrm{J}_{2}$ were analysed for WRR by continuously measuring their weights at various time intervals at ambient temperature until complete drying. The loss of water at different time intervals was plotted against time.

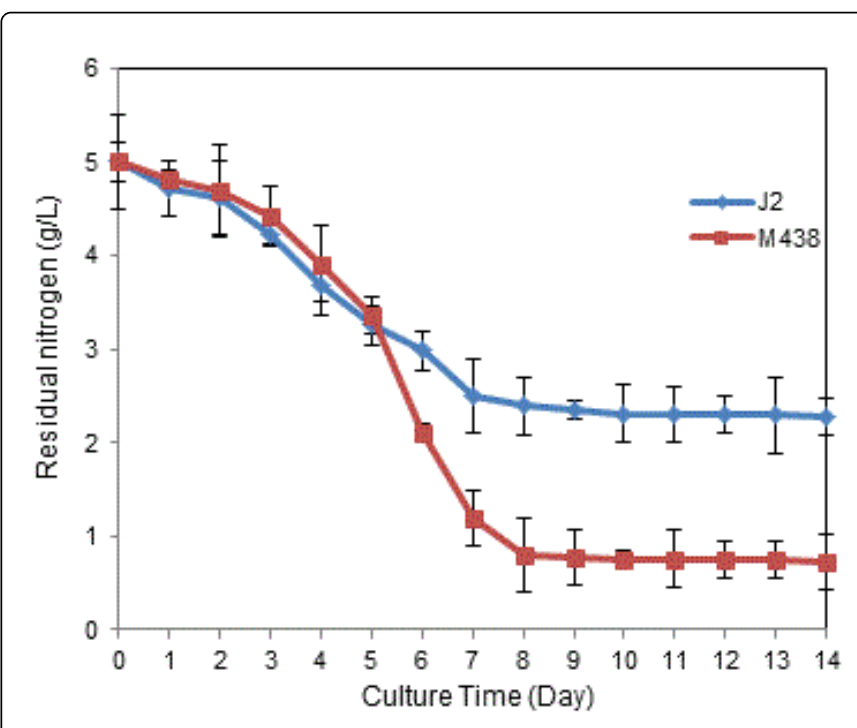

Figure 4: Residual nitrogen of medium from $\mathrm{J}_{2}$ and $\mathrm{M}_{438}$ during 14day fermentation.

\section{SEM observation}

For scanning electronic microscope observation, the freeze-dried $\mathrm{BC}$ membrane was mounted on a copper stub using double adhesive carbon conductive tape and coated with platinum for 30s using a platinum coating facility (Auto Fine Coater JFC-1300, Jeol, Japan). The SEM photographs were obtained by scanning electron microscope (JSM-6360LV, Jeol, Japan) at room temperature at $15 \mathrm{kV}$.

\section{FT-IR spectroscopy}

FI-IR spectra were recorded on these membranes using a Perkin Elmer FTIR Spectrum 100 System spectrometer equipped with a universal single bounce diamond ATR attachment: the resolution was $4 \mathrm{~cm}^{-1}$ after 32 scans. Spectra were collected from 4000 to $600 \mathrm{~cm}^{-1}$.

\section{Results}

\section{Morphology Characterization}

In the previous study, strain $\mathrm{J}_{2}$ and $\mathrm{M}_{438}$ were examined by Gram staining and both displayed gram-negative rod, straight, or slightly curved singly or in pairs, and cell shape of both strains was similar [14]. Furthermore, there was still no evident difference in colonies on plating medium. However, colonies of strain $\mathrm{M}_{438}$ were obviously bigger than those of $J_{2}$, although colonies of both strains $\mathrm{M}_{438}$ and $\mathrm{J}_{2}$ in liquid seed medium displayed transparent spheres after cultivation in a rotary shaker incubator at $150 \mathrm{rpm}, 30^{\circ} \mathrm{C}$ for $24 \mathrm{~h}$, (Figure 1 ).

\section{Fermentation parameters analysis}

Mutant strain $\mathrm{M}_{438}$ and its initial strain $\mathrm{J}_{2}$ were statically cultured at $30^{\circ} \mathrm{C}$ for 14 days in the same optimal fermentation medium. As the key fermentation parameters, cell density, residual nitrogen, residual sugar and total acidity of strain $\mathrm{M}_{438}$ and $\mathrm{J}_{2}$ were determined in this study.

As shown in Figure 2, the growth process of both strain $\mathrm{M}_{438}$ and $\mathrm{J}_{2}$ in seed medium included lag phase (0-2d), cell growth phase (2-6d), stationary phase (6-10d), and decline phase (10-12d). At the beginning of cell growth phase (2-4d), the growth rate of J2 was faster than that of $\mathrm{M}_{438}$, while the growth rate of mutant strain $\mathrm{M}_{438}$ was significantly faster than that of its initial strain after day 4.

As described in Figure 3, from day 0 to day 4, the residual sugar of both strain $\mathrm{M}_{438}$ and $\mathrm{J}_{2}$ decreased rapidly from $30 \mathrm{~g} \mathrm{~L}^{-1}$ to $15.47 \mathrm{~g} \mathrm{~L}^{-1}$ and $14.49 \mathrm{~g} \mathrm{~L}^{-1}$ respectively. After that, the residual sugar of $\mathrm{J}_{2}$ reduced slightly, then began to flatten and reached at $13.78 \mathrm{~g} \mathrm{~L}^{-1}$. While the residual sugar of $\mathrm{M}_{438}$ reduced significantly until $\mathrm{d} 7$ and leveled off at approximate $7.8 \mathrm{~g} \mathrm{~L}^{-1}$ in the left days. To sum up, during these 14 days, strain $\mathrm{M}_{438}$ consumed more carbon source, compared with $\mathrm{J}_{2}$. Moreover, the residual sugar of $\mathrm{J}_{2}$ was nearly doubled that of mutant strain $\mathrm{M}_{438}$.

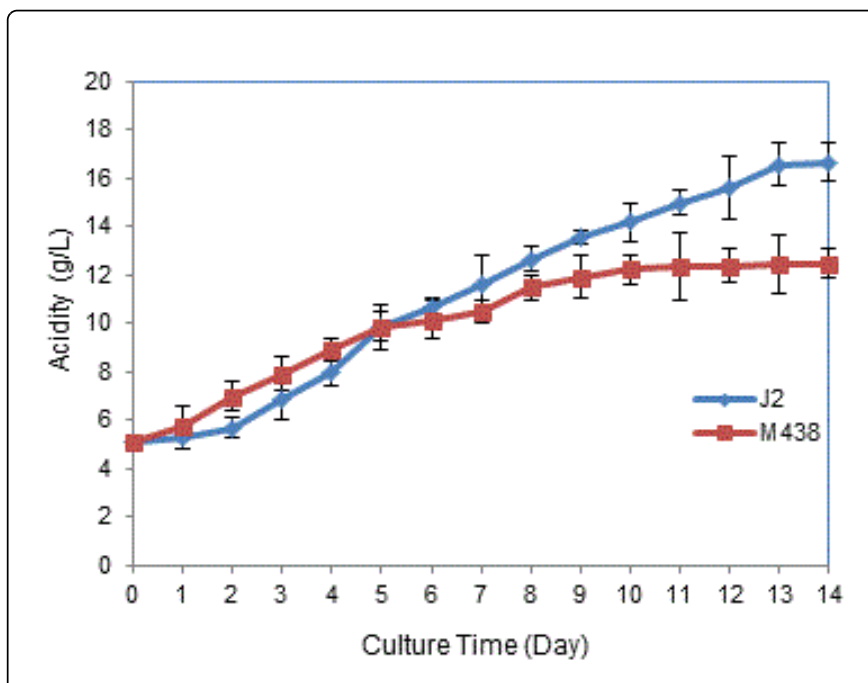

Figure 5: Acidity of medium from $\mathrm{J}_{2}$ and $\mathrm{M}_{438}$ during 14-day fermentation.

As can be seen in Figure 4, the nitrogen consumption trend was similar to sugar consumption trend. During the first 5 days (d0-d5) the residual nitrogen of M438 and $\mathrm{J}_{2}$ declined rapidly from $5 \mathrm{~g} \mathrm{~L}^{-1}$ to $3.36 \mathrm{~g}$ $\mathrm{L}^{-1}$ and $3.25 \mathrm{~g} \mathrm{~L}^{-1}$ respectively. After that, residual nitrogen of $\mathrm{J}_{2}$ continued to decrease until day 7 , then leveled off and arrived at $2.28 \mathrm{~g}$ $\mathrm{L}^{-1}$ on day 14 . While during that time strain $\mathrm{M}_{438}$ consumed nitrogen faster than strain $\mathrm{J}_{2}$ and the residual nitrogen was only $0.73 \mathrm{~g} \mathrm{~L}^{-1}$ on day 14. It was observed that residual nitrogen of $\mathrm{J}_{2}$ was nearly three times as that of $\mathrm{M}_{438}$. 
Page 4 of 6

Data from Figure 5 demonstrates that the mutant strain $\mathrm{M}_{438}$ and its initial strain $\mathrm{J}_{2}$ produced much acid during the fermentation period. The acidity increased with time and strain $\mathrm{M}_{438}$ produced more acid than strain $\mathrm{J}_{2}$ during the first 5 days, while after that, strain $\mathrm{J}_{2}$ produced more acid than strain $\mathrm{M}_{438}$ days. Furthermore, the acidity of strain $\mathrm{J}_{2}$ went gradually up to maximal value $17.03 \mathrm{~g} \mathrm{~L}^{-1}$ on day 14 , while the acidity of $\mathrm{M}_{438}$ increased slightly to $12.62 \mathrm{~g} \mathrm{~L}^{-1}$ on day 14 . It could be seen that the maximal acidity of $\mathrm{J}_{2}$ was significantly higher that of $\mathrm{M}_{438}$.

To sum up, mutant strain $\mathrm{M}_{438}$ grew faster than its initial strain $\mathrm{J}_{2}$ (Figure 4), therefore it consumed more carbon and nitrogen sources to supply energy, compared to strain $\mathrm{J}_{2}$. But during fermentation period, strain $\mathrm{J}_{2}$ produced more acid than strain $\mathrm{M}_{438}$, previous studies has demonstrated that high acid will inhibit the $\mathrm{BC}$ production [21]. Likely, that is one of the reasons that $\mathrm{BC}$ yield from strain $\mathrm{M}_{438}$ was more than three times as that from strain $\mathrm{J}_{2}$ [14]. It can be inferred that strain M438 has better properties compared with strain $\mathrm{J}_{2}$.

\section{WHC and WRR}

WHC and WRR were determined for estimating the usefulness of BC membranes in some medical areas [22] and food industries [23]. WHC of wet BC sample produced by M438 was found to be 105 times its dry weight, higher than that of $\mathrm{BC}$ produced by $\mathrm{J}_{2}$. It was obviously indicated that WHC of BC produced by $\mathrm{M}_{438}$ is better than that of BC produced by $\mathrm{J}_{2}$. The reverse was certainly true for WRR. Release of water from wet BC produced by M438 took more time as compared to that of $\mathrm{BC}$ produced by $\mathrm{J}_{2}$ (Figure 6). It needed nearly $60 \mathrm{~h}$ to completely release all the water from $\mathrm{BC}$ produced by $\mathrm{J}_{2}$, while it took almost $90 \mathrm{~h}$ to release all of the water BC produced by $\mathrm{M}_{438}$. The slow release of water from $\mathrm{BC}$ is important in biomedical applications and food additives.

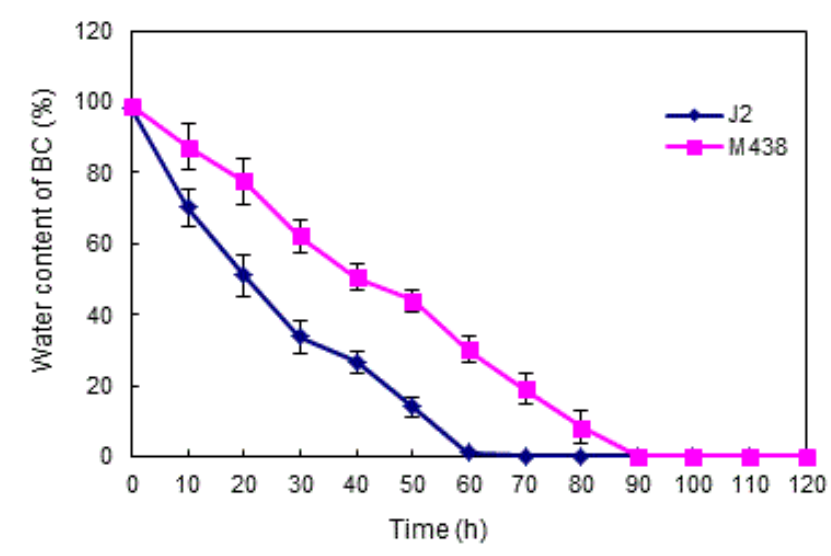

Figure 6: WRR of $B C$ samples from strain $\mathrm{J}_{2}$ and strain $\mathrm{M}_{438}$.

\section{SEM observation and FT-IR}

The microstructure of cellulose membrane was observed by SEM. Although multiple SEM micrographs were taken for the membranes produced from strain $\mathrm{J} 2$ and strain $\mathrm{M}_{438}$, only one representative micrograph is presented here (Figure 7). Micrographs obtained for these samples revealed a densely packed network of cellulose fibrils with few subtle differences between each sample. As observed by SEM
(Figure 7), it shows that the micro-fibrils of BC membranes from $\mathrm{J}_{2}$ and $\mathrm{M}_{438}$ were randomly arranged with plenty of spaces among them. This arrangement of fibrils results in the formation of pores with different diameters on the surface and through the entire matrix of the $\mathrm{BC}$ sheets. So the water molecules can be sandwiched between pores of the thick fibrils, and these fibrils act as a shield for water molecules. Hence, these fibrils display high water holding capacity. Results from SEM images of Figures $7 \mathrm{a}$ and $7 \mathrm{~b}$ suggest that fibrils of $\mathrm{BC}$ produced by $\mathrm{J} 2$ were the same as those of $\mathrm{M}_{438}$ in fibril size, while there were more pores in the fibrils of $\mathrm{BC}$ produced by $\mathrm{M}_{438}$ compared with those of $\mathrm{J} 2$ (Figures $7 \mathrm{c}$ and $7 \mathrm{~d}$ ). It was reported that $\mathrm{BC}$ membranes with more pores have high WHC capacity [24]. Therefore the higher WHC of $\mathrm{BC}$ produced by $\mathrm{M}_{438}$ may be due to more pores.

As can be seen in Figure 8, there was no evident differences between these two membranes. And both were consistent with the result reported in the previous literature [25].

\section{Discussion}

In this study, the different characterizations of $\mathrm{M}_{438}$ and $\mathrm{J}_{2}$ should be induced by HHP. Of course, another possibility was not still removed completely, that is, this mutant strain was from the presence of potential mutant strains in test strains. However, the test strain used every time was from pure culture of a single colony. Therefore, there is very little possibility that the mutant strain was obtained from screening naturally.

As a key physical parameter, the pressure exerts an important influence on the viability and biological activity of organisms. A wide variety of high pressure-induced phenomena in living cells have been reported and reviewed, including changes in cellular morphology, biochemical reactions, genetic mechanisms, and membrane integrity $[26,27]$. In the previous study, it was found that only $0.5 \%$ of strains can survive after strain $\mathrm{J}_{2}$ treated by $\mathrm{HHP}$ for $15 \mathrm{~min}$ at $25^{\circ} \mathrm{C}, 250 \mathrm{MPa}$ [15], which is the same pressure as that in deep sea of 25,000 m depth where only piezophilic microbes can survive. Previous report showed that G. xylinus ATCC53582 cells were cultivated under culture conditions within $0.1-100 \mathrm{MPa}$ and can grow well without undergoing morphological changes. It also maintains its cellulose producing ability but only produces a little BC [28]. While in this study, Colonies of strain M438 in liquid seed medium were bigger than those of its initial strain $\mathrm{J}_{2}$ and fermentation parameters of strain $\mathrm{M}_{438}$ were different from those of strain $\mathrm{J}_{2}$. Maybe it is probably due to the different magnitude and duration of treatment. Up to date, there are few reports about polysaccharide production by microorganism after treatment by high hydrostatic pressure under the high pressure of $250 \mathrm{MPa}$, so no one has known the sensitivity of polysaccharide producing protein inside the cells $[28,29]$. It is widely recognized that cell growth in organisms is inhabited by pressure [13]. However, in the present study the mutant strain $\mathrm{M}_{438}$ treated by HHP grew faster than its initial strain. According to the fermentation parameters, metabolism of strain M438 was faster, compared to those of strain $\mathrm{J}_{2}$.

Additionally, there were no evident differences in the properties of $\mathrm{BC}$ membranes to some extent, except for that the $\mathrm{BC}$ yield increased significantly after HHP treatment [15]. However, WHC of BC membranes produced by mutant strain M438 was a little higher and wet $\mathrm{BC}$ membranes took more time to completely to remove water in $\mathrm{BC}$, compared to those of strain $\mathrm{J}_{2}$. BC is formed on the surface of a bacterium through a linearly ordered array of terminal complexes (TCs) composing of cellulose synthesis protein units that give rise to 
sub-elementary fibrils [30]. These fibrils are extruded out of TC subunits via the pores aligned on the lipo-polysaccharide membrane of the bacteria. In addition, the structure of the micro-fibrils varies among cellulose producing organisms depending on the array of TCs on their cell surface. Therefore it would be concluded that characteristics of $\mathrm{BC}$ membranes have closely connection with membrane of the bacteria [30]. However, in this study strain was treated by HHP, which can induce a series of changes in cells. It has been reported that pressure disturbs the equilibrium of chemical reactions towards volume reduction, besides the structural alterations in biomolecules [12]. This phenomenon is driven by the smaller volume associated with a more ordered, tighter packing, which leads to a decrease in cell membrane fluidity followed by an increase in thickness. Pressure around $200 \mathrm{MPa}$ can generate important conformational alterations that lead to modifications in enzymatic reactions as well as protein interactions and functionality [12]. In this way, $250 \mathrm{MPa}$ are sufficient to induce a series of reactions in cells. In our previous work, we did some fundamental research at molecular level and found that strain M438 was a deletion mutant induced by HHP compared to strain $\mathrm{J}_{2}$ [14]. All the changes should be owing to the gene mutation after treatment by HHP. As the effects are very complex, we will particularly investigate the molecular mechanism of microbial mutation HHP-induced in our future work.

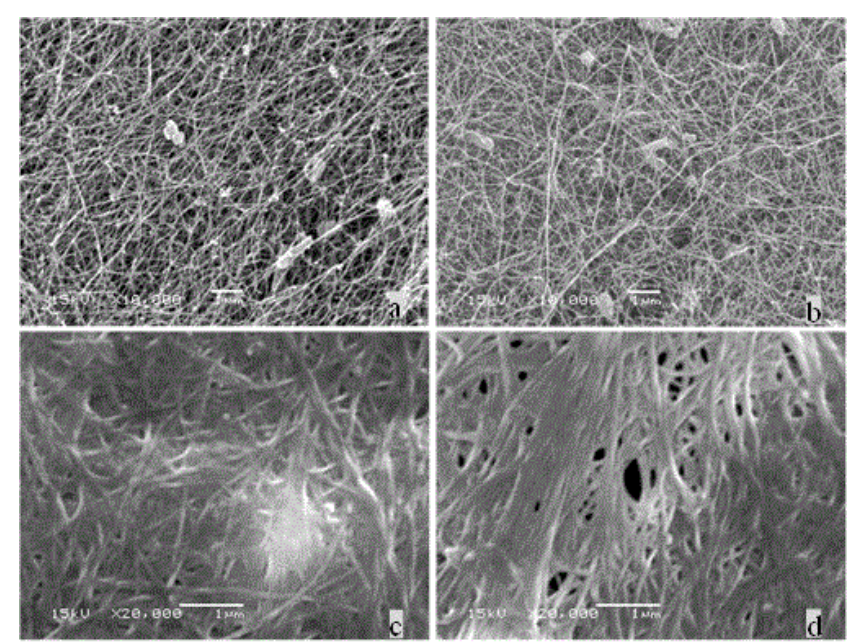

Figure 7: SEM images of BC membranes from strain $\mathrm{J}_{2}(\mathrm{a}, \mathrm{c})$ and M438 (b, d).

To sum up, it confirmed that high hydrostatic pressure was a safe and effective mutating method to cause mutagenesis, it did not change the specific properties of $\mathrm{BC}$ membranes, on the contrary, it improved $\mathrm{BC}$ yield and improved the characterizations of strain $\mathrm{J}_{2}$ to some extent.

\section{Acknowledgement}

The authors were thankful to Dr. Wu Ruiqin for technical support and Dr. Ge Hanjing for valuable suggestions. This work was financially supported by the Fundamental Research Funds for the Central Universities (QN2009072).

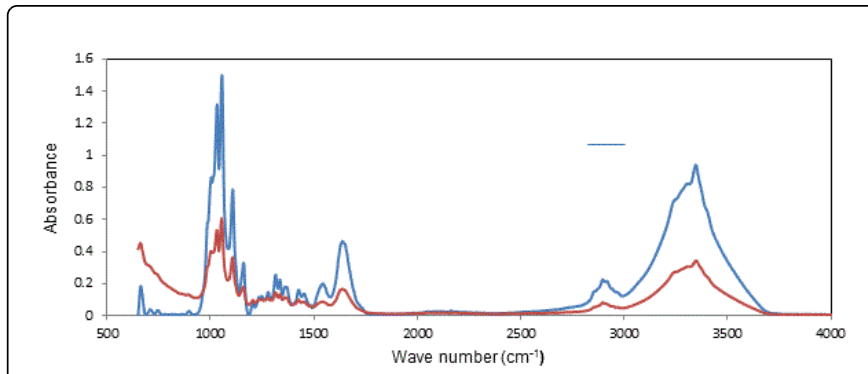

Figure 8: FT-IR spectra of bacterial cellulose produced by strain $\mathrm{J}_{2}$ and $\mathrm{M}_{438}$.

\section{References}

1. Bernardo E, Neilan B, Couperwhite I (1998) Characterization, Differentiation and Identification of Wild-type Cellulose-synthesizing Acetobacter strains Involved in Nata de Coco Production. Systematic and applied microbiology 21: 599-608.

2. Klemm D, Heublein B, Fink HP, Bohn A (2005) Cellulose: fascinating biopolymer and sustainable raw material. Angew. Chem. Int. Ed. 44: 3358-3393.

3. Klemm D, Kramer F, Moritz S, Lindström T, Ankerfors M, et al. (2011) Nanocelluloses: A New Family of Nature-Based Materials. Angew Chem Int Ed. 50: 5438-5466.

4. Klemm D, Schumann D, Udhardt U, Marsch S (2001) Bacterial synthesized cellulose-artificial blood vessels for microsurgery. Prog Polym Sci 26: 1561-1603.

5. Petersen N, Gatenholm P (2011) Bacterial cellulose-based materials and medical devices: current state and perspectives. Applied microbiology and biotechnology 91: 1277-1286.

6. Andrade FK, Costa R, Domingues L, Soares R, Gama M (2010) Improving bacterial cellulose for blood vessel replacement: Functionalization with a chimeric protein containing a cellulose-binding module and an adhesion peptide. Acta Biomater 6: 4034-4041.

7. Eichhorn S, Dufresne A, Aranguren M, Marcovich N, Capadona J, et al. (2010) Review: current international research into cellulose nanofibres and nanocomposites. Journal of Materials Science 45: 1-33.

8. Iguchi M, Yamanaka S, Budhiono A (2000) Bacterial cellulose-a masterpiece of nature's arts. J. Mater Sci 35: 261-270.

9. Phisalaphong M, Chiaoprakobkij N (2012) Applications and ProductsNata de Coco. Bacterial Cellulose: A Sophisticated Multifunctional Material 9: 143.

10. Svensson A, Nicklasson E, Harrah T, Panilaitis B, Kaplan D, et al. (2005) Bacterial cellulose as a potential scaffold for tissue engineering of cartilage. Biomaterials 26: 419-431.

11. Lammi MJ, Elo MA, Sironen RK, Karjalainen HM, Kaarniranta K, et al. (2004) Hydrostatic pressure-induced changes in cellular protein synthesis. Biorheology 41: 309-313.

12. Fumiyoshi A (2007) Exploration of the effects of high hydrostatic pressure on microbial growth, physiology and survival: perspectives from piezophysiology. Biosci Biotechnol Biochem 71: 2347-2357.

13. Wuytack E, Diels A, Michiels C (2002) Bacterial inactivation by highpressure homogenisation and high hydrostatic pressure. International Journal of Food Microbiology 77: 205-212.

14. Ge H, Du S, Lin D, Zhang J, Xiang J, et al. (2011) Gluconacetobacter hansenii subsp. nov., a High-Yield Bacterial Cellulose Producing Strain Induced by High Hydrostatic Pressure. Appl Biochem Biotechnol 165: 1519-1531.

15. Wu R, Li Z, Yang J, Xing X, Shao D, Xing K (2010) Mutagenesis induced by high hydrostatic pressure treatment: a useful method to improve the 
Citation: $\quad$ Lin D, Wang N, Li Z, Li Y (2014) Characterizations of Bacterial Cellulose Producing Strain Gluconoacetobacter hansenii CGMCC3917. J Bioproces Biotechniq 4: 160. doi:10.4172/2155-9821.1000160

Page 6 of 6

bacterial cellulose yield of a Gluconoacetobacter xylinus strain. Cellulose 17: 399-405.

16. Guo Y, Pan D, Tanokura M (2009) Optimisation of hydrolysis conditions for the production of the angiotensin-I converting enzyme (ACE) inhibitory peptides from whey protein using response surface methodology. Food Chemistry 114: 328-333.

17. Yin J, Xu Y, Yuan H, Luo L, Qian X (2009) Cream formation and main chemical components of green tea infusions processed from different parts of new shoots. Food Chemistry 114: 665-670.

18. Wang W, Guo S, Li L, Wang M, Liang G (2008) The determination of protein content in polysaccharides from stanuntonia chinensis with coomassie brilliant blue method. Food Research and Development 1: 037.

19. Kurosumi A, Sasaki C, Yamashita Y, Nakamura Y (2009) Utilization of various fruit juices as carbon source for production of bacterial cellulose by Acetobacter xylinumNBRC 13693. Carbohydr Polym 76: 333-335.

20. Shezad O, Khan S, Khan T, Park JK (2010) Physicochemical and mechanical characterization of bacterial cellulose produced with an excellent productivity in static conditions using a simple fed-batch cultivation strategy. Carbohydr. Polym 82: 173-180.

21. Mohite BV, Salunke BK, Patil SV (2013) Enhanced Production of Bacterial Cellulose by Using Gluconacetobacter hansenii NCIM 2529 Strain Under Shaking Conditions. Applied biochemistry and biotechnology 169: 1497-1511.

22. Ciechańska D (2004) Multifunctional bacterial cellulose/chitosan composite materials for medical applications. Fibres \& Textiles in Eastern Europe 12: 48.
23. Vandamme E, De Baets S, Vanbaelen A, Joris K, De Wulf P (1998) Improved production of bacterial cellulose and its application potential. Polym Degrad Stab 59: 93-99.

24. Ougiya H, Watanabe K, Matsumura T, Yoshinaga F (1998) Relationship between Suspension Properties and Fibril Structure of Disintegrated Bacterial Cellulose. Bioscience, biotechnology, and biochemistry 62: 1714-1719.

25. Tokoh C, Takabe KJ, Fujita M (2002) Cellulose synthesized by Acetobacter xylinum in the presence of plant cell wall polysaccharides. Cellulose 9: 65-74.

26. Bartlett DH (1992) Microbial life at high pressures. Science progress 76 : 479-496.

27. Bartlett DH (2002) Pressure effects on in vivo microbial processes. Biochim Biophys Acta 1595: 367-381.

28. Kato N, Sato T, Kato C, Yajima M, Sugiyama J, et al. (2007) Viability and cellulose synthesizing ability of Gluconacetobacter xylinus cells under high-hydrostatic pressure. Extremophiles 11: 693-698.

29. Ishii A, Sato T, Wachi M, Nagai K, Kato C (2004) Effects of high hydrostatic pressure on bacterial cytoskeleton FtsZ polymers in vivo and in vitro. Microbiology 150: 1965-1972.

30. Brown R, Montezinos D (1976) Cellulose microfibrils: visualization of biosynthetic and orienting complexes in association with the plasma membrane. Proceedings of the National Academy of Sciences 73: 143-147. 